\title{
THE ETHICAL AND AESTHETICAL DIMENSION OF FIGURATIVE CLASSICAL CALLIGRAPHY PAINTING
}

\author{
Dini Kurniawati \\ Komunitas Seni Kaligrafi Malang \\ Dini_kurni@gmail.com
}

\begin{abstract}
The current phenomenon indicates that the use of the term of art experienced a shift in meaning, which is arbitrary. Art is only seen as an expression of free expression, without care about the meaning contained in the work of art. However, it is not evident among Moslem artists in expressing their work in figurative calligraphy painting. Although in Islam, painting especially in paint the creature living (figure) got a bad response, but the Moslem artists were able to present works that are not only beautiful but also the messages. The research questions in this thesis are first what is the ethical and aesthetical message of figurative calligraphy painting? And is there a relationship between ethical and aesthetical messages in figurative calligraphy painting? Trough an interpretative qualitative and a symbolic interaction approach. The research concluded that the ethical messages are Posts contain praying illustrated in the form of 'abid in praying. It contains the meaning that human is weak creature and always does wrong. Therefore, humans need forgiveness from Allah. Posts of Ali Ibn Abi Thalib was illustrated in the form of lion. It describes and contains the meaning of braveness and heroism of Ali in defense of Allah religion. The aesthetical message in every figurative calligraphy painting is a manifestation of the beauty that exists in the universe. Figurative calligraphy painting is described the Majesty, Power and Oneness of Allah, the art was created is the manifestation of tawhid.
\end{abstract}

Keywords: Calligraphy Painting, Aesthetic, Isamic Art

\section{A. Introduction}

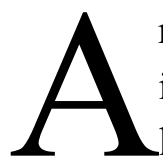

$\mathrm{rt}$ is a wonderful sense of embodiment contained in the human soul generated by intermediate means of communication into a form that can be captured by the listener sense (voice art), sight (painting) and motion (dancing, theater). Other meaning, art is a man"es work comes from the mind and aesthetic feelings that can arouse heart live. According to Herbert Read, art is effort to create happiness forms. ${ }^{1}$

\footnotetext{
${ }^{1}$ Sidi Gazalba, Asas Kebudayaan Islam; Pembahasan Ilmu Dan Filsafat Tentang Ijtihad, Fiqih, Akhlak, , Bidang-Bidang Kebudayaan, Masyarakat, Negara,(Jakarta: Bulan Bintang,1978), 299.
} 
Islam recognizes fitrah and instinct of people as created by Allah, where He created them as creature who likes happy, fun, laughing and playing, as it likes to eat and drink. ${ }^{2}$

Ilähies Law plays an importance role to create an environment and background to Islamic art. ${ }^{3}$ Basically, Illăhi s Law contains the commands for Moslem about how to do. Its influence on art is to give the general social background, and also create the soul of artists with nature inspired and policies derived from the Qure an and Hadith. To understand the dimensions of the soul of Islam, then had to switch to the forerunner of Islamic art. ${ }^{4}$ All of Islamic art evolving to fulfill the divine transcendence becomes highest aesthetic principles. All of Islamic art develop stylization as denaturalization, so it is nondevelopmental and non-figurative. ${ }^{5}$

Artist is someone who expresses the variety of feelings, ideas and expression in a work of art. They understand the art more deeply than others, so as the definition of art above especial Islamic art; ideally, it will have an impact on their work, as a Moslem artist is able to create a good and beautiful work. Because, their work as well as self-expression it will also be to the public art. It does not only show the aesthetic value but also able to translate ideas and messages in his work properly. Basically, there is no art with just a story, but there is an idea and message. In addition, they must take responsibility for their work that they serve, both to themselves and to society as the public art.

In fact, lately in daily phenomena art is not the case anymore. The term of art used arbitrarily. Indeed, basically everyone is an artist. Just like human is religion man, social man, economic man, politic man, thinker from the philosophical term. But in the daily life, artist is certain people who have a sense of feeling and often he was moved to create a

${ }^{2}$ So many scholars had a notion that art is not has relation with religion especially in Islam. So, it has to leave, even a statement, it is haram. They have a notion that Islam is just a religion; mean the relation between human and God. That opinion is not completely wrong, in relationship with God is not need an art, because God does not persuade with singings or dancing. He just requires the god-fearing from His creature. Actually Islam is as ad-din not only as just religion, but as the culture too. Where the culture is result of activity and the creation of human spirit (reason)-include believing, art and custom. As the universal cultural, it met in every culture since early till now, also in Islamic culture. Although art position is in the culture, but the tendency of art could be found in religious area. Example; reciting of Holy Qur'ean by Tilawah, boom out of Adzan by melodiously. See Sidi Gazalba, Asas Kebudayaan Islam; Pembahasan Ilmu Dan Filsafat Tentang Ijtihad, Fiqih, Akhlak, , Bidang-Bidang Kebudayaan, Masyarakat, Negara, (Jakarta: Bulan Bintang,1978), 302.

${ }^{3}$ Work of art ${ }^{\mathrm{e}} \mathrm{s}$ category as Islamic art is not just because created by Moslem, but also based on revelation. Islamic art is protracting the realities of Islamic revelation spirit in the form world and come out from Islamic spirit dimension to Ilahi revelation spirit. See on Seyyed Hosein Nasr, Spiritualitas Dan Seni Islam, translator: Drs. Sutejo, (Bandung: IKAPI, 1993), 17.

${ }^{4}$ Causal relationship between the revelation of Islam and Islamic art is evidenced by the organic relationship between art and worship. Between the contemplation of God in the Qur'an with contemplation of the nature of art, namely remember Allah as the final destination of all Islamic worship. See. Seyyed Hosein Nasr, Spiritualitas Dan Seni Islam, Translator: Drs. Sutejo, (Bandung: IKAPI, 1993), 14.

${ }^{5}$ Isma'il Raji Al Faruqi, Tawhid;It's Implication for Thought and Life, translator: Rahmani Astuti, (Bandung: Pustaka, 1982), 70. 
works, probably about the skill and ability to give shape to his imagination, so it can be enjoyed by public art. ${ }^{6}$

Today many phenomena that can be encountered in everyday life, many impromptu artists express ideas in a work regardless of his work can be accepted in society or not. They do not care about the consequence afterwards. Sometimes, their work rather than contribute meaningfully in society, but it becomes a conflict. They make the work only as a form of expression. They do not care about the importance elements of art. Art becomes absurd with no clear boundaries. People tried to open these limits by saying the name of art. They forget the most important element in creating a work of art; art directed and guided religion, in addition to the aesthetic value, work of art must contain the ethics value. ${ }^{7}$

Commonly, in the Eastern art, the function of art is a medium of religious worship. The content and form of art, either technic or aesthetic and the message cannot be separated from its function. It required the art method which is based on the teachings of religion and cult king. Art method becomes a low and art concept is the source of artistic creation. ${ }^{8}$

Most of Islamic society avoiding art because it is based on Western art meaning. Art is the art of idolatry that definitively developed by pagan. In fact, art from the West spawned a variety of high achievement that can make art lovers lost in dreams, and their feeling will float in a dreamland. What is directed by wataniyah art has decorated all of art form, by aesthetic and its magic formula. Therefore, fine of art is synonymous with the western art gets a bad response in Islamic society. ${ }^{9}$

Fine of art is creation world that produce a variety of idea that set the river on fire means amazed or agree and sometimes make sensitively problem in the society (conflict). Even less is about Moslem view of painting. It happens because ambivalent in Islamic law, especially for paint the living creature (human and animal). That is too extreme and too permissive attitude; keep in mind this problem is more about feeling and heart than mind. ${ }^{10}$

As the history of Islam, prophet Muhammad forbade for paint special the living creature. Nevertheless, moslem artists choose to be more careful in expressing his ideas. They prefer to avoid the situation; they paint according to the flow of feelings and artistic inspiration that sticks to the ethics of Islam. They have their own style in painting living creature; they are distanced from element of motion that is argument of life and shy away from its natural form. In creating work of art, moslem artists do not only want to show the

\footnotetext{
${ }^{6}$ Sanento Yuliman, Dua Seni Rupa, (Jakarta: Kalam, 2001), 26

${ }^{7}$ Sidi Gazalba, op. cit., 301

${ }^{8}$ Wiyoso Yudoseputro, Pengantar Seni Rupa Islam di Indonesia, (Bandung: Angkasa,t.th), 5.

${ }^{9}$ Wiyoso Yudoseputro, Pengantar Seni Rupa Islam di Indonesia, Bandung: Angkasa, t.th., 11

${ }^{10}$ Yusuf Qardhawi, Islam dan Seni, penerjemah: Zuhairi Misrawi, (Bandung: Pustaka Hidayah, 2000), cet. I, 17.
} 
aesthetics value of work, but also they want to show the messages of the works. Although, in the reality the art ${ }^{\text {ee }}$ public does not understand the meaning contained in the work.

In creating work of art, artists always need a big freedom. Their imagination in the work will appear if there is no ties or rules surrounding. It also applies to calligraphical painting; in general, they paint without involving the rules pattern "Khattiyah".it become a conflict among pure calligrapher (stick to the rules of pattern khattiyah), the painter of calligraphy is considered deviant. This is caused by many mistakes due to lack of capitalization prudence in their paintings. Neither mistakes in putting the point, shortage of nibrah, less or more the points. Therefore, it feared would result in different meanings. ${ }^{11}$

There is an expression; calligraphy art is described as a sense of beauty, sense ambassador, advisor mind, knowledge of weapons, and tamer brother in contention, longdistance calls, secret storage, and repertoire of the problems of life. Therefore, calligraphy is described as a spirit in the body. As calligrapher, they are required to keep the error from any point though, either in meeting the aesthetic or functional purpose. ${ }^{12}$

In this case, the form of classical calligraphy has several advantages compared to modern forms in displaying the meaning. The form of classical calligraphy is in several nations which incidentally rapid famous development of calligraphy. Like Persia, Turkey, India and Egypt. The artists of Persia, Turkey and India used Thuluth, Naskhi, Ta'liq and Nasta'liq in creating and modified the figurative forms in calligraphy. ${ }^{13}$

In creating the work, they have the unique character, often in the form of bird, this form identic with Turkey and Persia. The combination of calligraphy and ornamentation in the classical figurative calligraphy has several aspects and benefits. First are visual beauty that can be enjoyed and the cause of pleasure and admiration. Second is pushing to get closer to Allah SWT by permeates the meaning contained in the text. And third is as the height symbols of art and Islamic culture. ${ }^{14}$ From this, it can be known that the meaning and messages of calligraphy is not only stressed in aesthetics value, but also ethics and theology. Because, in the fact the beautiful works do not necessary have the ethical values.

This article tries to answer two quetions: What is the ethical and aesthetical message of figurative calligraphy painting? Is there a relationship between ethical and aesthetical messages in figurative calligraphy painting?

\footnotetext{
${ }^{11}$ Oliver Leaman, Menafsirkan Seni Dan Keindahan; Estetika Islam, translator: Irfan Abubakar, (Bandung: Mizan, 2005), cet. Ke-I, 49.

${ }^{12}$ Kamil al-Baba, Dinamika Kaligrafi Islam, translator; Drs. D. Sirojuddin AR., (Jakarta: Darul Ulum Press, 1992), 48.

${ }^{13}$ D. Sirojuddin AR. Seni Kaligrafi Islam, (Jakarta: Pustaka Panjimas, 1985), 155.

${ }^{14}$ C. Israr. Dari Teks Klasik Sampai ke Kaligrafi Arab, (Jakarta: Yayasan Masagung, 1985), 152.
} 


\section{B. Ethic and Aesthetic of Art in Islamic Perspective}

Ethics of art is a means of orientation for artists attempt to answer the question in the work. The question must be answered is the fundamental question, how do artists have to work? The answer is not a description of moral truth pertaining to teachings, exhortations, and standards how artist acts in the creation of works of art. Nor is a description of this rule and that gives the connotation instructions on how to become a good artist. But, ethics is intended as a description of the phenomenon epistemological orientation work, which centered on the issue of the use of mediums, ordinances, creation, and the beauty of artistic choices legitimate requirement in the work.

It was with the aim that in the work of artists not only went along with or mimics other people's work. Because then, the artists will understand the related works of art they created, why should it be like this or like that. Because, in addition to his work as a selfexpression will also be to the community. Basically, ethics of art helps artist to be able to responsible for the work that they serve both to themselves and to society. In the work, artist always request a lot more than others, on the grounds that the imagination cannot be limited by any rule or law. But, freedom and responsibility are two sides of the coin of ethics that should be there. K. Bertens revealed that there is a reciprocal relationship between the meaning of freedom and responsibility, free of doing things, but also be prepared on the consequences. It means to be responsible of each behavior performed. ${ }^{15}$

Ethics of art is not a limitation of social or cultural boundaries, which is essentially the source of the traditions, customs evolved in society, religion and certain ideology. But, ethics of art is philosophy or critical thinking and fundamental about the use of and management of the media as a medium, as well as the procedures for the creation of the moral teaching of the values that will be the object and the content of the expression of art. At its core, ethics of art is the systematic thinking about the values of the choice of medium, method, and content of the work in the creation of art. ${ }^{16}$

Creating paradigm is the part of discipline epistemology of art that contain the elements that was thought by artist. The elements consist of basic belief, model, concept and method. ${ }^{17}$

Basic belief is the view that is personal, subjective, which could have been derived from the philosophical point of views, theories or profound reflections on empirical experiences. Impossible, that there is work of art without the basic beliefs of the artist. The

\footnotetext{
${ }^{15}$ Bertens, K, Etika, (Jakarta: Gramedia Pustaka Utama, 1993), 81.

${ }^{16}$ Ibid., 83.

${ }^{17}$ Ahmad Amin, Etika, (Jakarta: Bulan Bintang, 1975), 112.
} 
basic beliefs can be a source of confidence, medium, and procedure for the creation, validity and terms of artistic choice. ${ }^{18}$

According to I Wayan Sadra, the first orientation of artist in work is value. Value is view or belief about something good, beautiful, and true that is expected to occur. Because, value related to option, thought, and personal action, then beliefs about good and right is determined by the artist themselves. According to him, the good work is the work that is created based on a good understanding of the reality of the truth object for his work. The reality of the truth is not sensory, but the essence is spiritual or idea. ${ }^{19}$

Goodness and truth of art is contemplative and imaginary, and in understanding it must use reasoning, reflection and imagination to reach knowledge about the nature of the problem and the impressions or concepts that do not exist in the sense. Imagination is the ability to connect and combine the representations and ideas freely. ${ }^{20}$

In the other side, art works like painting has aesthetic aspect. It is beautiful value, where beauty means good, beautiful, pretty and cute. Beautiful thing is called work of art (although not all of work of art is beautiful).61 Herbert Read in his book, "The Meaning of Art" beauty is the unity of formal relations among our senseperceptions. ${ }^{21}$

Beautiful as the value that is ideal; it is not fact because there is no existential beyond human beings. A works or things, which is said to be beautiful is its beauty is not found in the works or things themselves, but it is feeling internalized. Beautiful is a term for objects that give rise to a peculiar pleasure that is called aesthetic .

In the painting, painting has an idea or ideas that are personal, but it can have broad impact. The impact was such pro and contra in the community. True artists create art to make man a more humane and civilized. Without constituted by a basic knowledge of the principles of aesthetics, it can unwittingly create disharmony and dehumanization. ${ }^{22}$

From the previous discussion has been explained on the ethics and aesthetics, both turn out in the discussion of the science that is closely associated with each other. In this case can be seen that both of science discussed about the value, ethic is the value of behavior and aesthetic is the value of beauty. The ethical value is the ethics for human as the intact personal. The value related to akhla $q$, that associated with right and wrong that is shared by a group. The ethical value is very important for human, because therein lied the

\footnotetext{
${ }^{18}$ Ahmad Amin, Etika, (Jakarta: Bulan Bintang, 1975), 112.

${ }^{19}$ Franz Magnis Suseno, Etika Dasar Masalah-masalah Pokok Filsafat Moral, (Yogjakarta: Kanisius, 1997), 39.

${ }^{20}$ Franz Magnis Suseno, Etika Dasar Masalah-masalah Pokok Filsafat Moral, (Yogjakarta: Kanisius, 1997), 40.

${ }^{21}$ Hamdy Salad, Agama Seni Refleksi Teologis dalam Ruang Estetik, (Yogyakarta: Yayasan Semesta, 2000), 104.

${ }^{22}$ Donald M. Borchert, Philosophy and Ethic, (Macmillan Library, 1996), 55
} 
humanity that distinguishes man from animals. The ethical value is the basic foundation on humanity value that understands about religion. ${ }^{23}$

While, the aesthetic value is the value is based on the beauty. This value is also important for human, because with the beauty will give the color in life, then the human will feel comfortable in life. By nature, human beings love things related to beauty. ${ }^{24}$

Both of values related with the cultural products. Human equipped with a reasonable, ethical and aesthetic values corresponding to the values of humanity, so in that case can be distinguished between human and animal.

In philosophy, the term of value is often used as an abstract noun meaning the worth or goodness. In the Dictionary of Sociology and Related Sciences, value is the believed capacity of any object to satisfy a human desire, the quality of any object which causes it to be of interest to an individual or a group. Value is a psychological reality that must be distinguished clearly from the usefulness, because there are in the soul and not the thing. In the philosophy the issues of the value are reviewed by one of its branches called axiology, or the theory of value. Key issues discussed and until now there is still no unified ideology is about the types of value and the metaphysic status of value. ${ }^{25}$

About the variety of value, there is opinion that differs between subjective and objective value. Other difference is between personal and community value. But, according to the experts is difference between extrinsic and intrinsic value. Extrinsic value is the good nature or worth of an object as a tool or medium to other things. It is often called contributory value; it is the value is a tool or help. While, the intrinsic value is the good nature or valuable in itself or it is as a destination for its own sake or for the sake of the object. It is called consummator value; it is the complete or reaches the dream. Commonly, that recognized as an intrinsic value is truth, goodness and beauty, or it called positive value. And the contrary, negative value is for something that is not good. The problem of the metaphysic status of value consisted of the value relate to value and fact. This problem was answered by two opinions that known as subjectivity and objectivity establishment. Subjectivity establishment states that the value is entirely dependent on and related to the value of human experience. Then, objectivity establishment states that the values are the elements that are joined together, objective and active from the metaphysical reality. ${ }^{26}$

\footnotetext{
${ }^{23}$ Pickthall, Muhammad Marmaduke, The Cultural Side of Islam (Islamic Culture), (New Dehli: Kitab Bhavan, 1981), 47.

${ }^{24}$ Donald M. Borchert, Philosophy and Ethic, (Macmillan Library, 1996), 60.

${ }^{25}$ Donald M. Borchert, Philosophy and Ethic, (Macmillan Library, 1996), 62.

${ }^{26}$ Donald M. Borchert, Philosophy and Ethic, (Macmillan Library, 1996), 65-69
} 


\section{Classical Figurative Calligraphy Painting}

Calligraphy art is the greatness of Islamic art that emerged in the middle of the architecture. It can be proved in a variety of calligraphy decorative that meet in the mosques and other buildings, which are expressed in the fusion of the Qur'an verses, Hadith and the words of wisdom.

Calligraphy differed to be two categories; pure calligraphy and painting calligraphy. Pure Calligraphy is beautiful writing art that follows the rules of pattern khattiyah. Irregularities or confounds between one khat and other khat is regarded as an error, because basically it was not compatible with the existing formula, for each writing a different script. $^{27}$

Lately, it seems the cultivation of calligraphy, either the rules of "khatttiyah" or "more freedom" to be painting. Pure calligraphy is experiencing to be new forms of expression in the letter composition, it combined with a decorative motif or it called calligraphy painting. The definition of painting is the artistic experience that is expressed in twodimensional plane using color and line.While painting calligraphy is model calligraphy inscribed on the work of painting, or calligraphy graffiti painted using a variety of colors and not bound to the rules of pattern "khattiyah". ${ }^{28}$

The definition of Islamic calligraphy painting is not always show to the development of calligraphy styles mean letter. ${ }^{29}$ Focus of calligraphy painting is not only finishing to the letter, but its present as the painting in real meaning. The critic of fine art, Dan Suwaryono insisted that the calligraphy painting are basically supported by two elements of art; fisiko plastis (form, line, color, space, light, and volume) and demands that tends toward idio plastis (include all the issues that directly or indirectly relate with content and form), simply, calligraphy painting is not only show the letters which is painted, but also as the real painting that make the letters as one of its elements.

According to Affandi, calligraphy painting is the work of man as the result of the processing of inner expression through writing elements arrangement and other twodimensional elements, which has a symbolic nature, religious, and aesthetic and bring the ethic message between human and God, human and human, and human and nature. ${ }^{30}$

Every calligraphy painting has freedom style or type of writing, so to create a unity of painting form that suit with desire of creator. From the definition of calligraphy painting, it can be said that; first, calligraphy painting is not only as the art of beautiful writing.

${ }^{27}$ The patterns of Islamic calligraphy are Naskhi, Tsuluts, Rayhani, Diwani, Diwani Jali, Farisi, Kufi, dan Riq"ah. See, D. Sirojuddin AR. Seni Kaligrafi Islam, (Jakarta: Pustaka Panjimas, 1985), 9.

${ }^{28}$ Soedarso, Seni Lukis Kaligrafi Islam, (Yogyakarta: ISI, 1992), 10.

${ }^{29}$ Isma'il Raji Al-Faruqi, Seni Tauhid Esensi dan Ekspresi Estetika Islam, translator; Hartono Hadikusumo, (Yogyakarta: Yayasan Benteng Budaya, 1999), 105-118.

${ }^{30}$ M. Affandi, Ekspresi Simbolik, Religius dan Estetika dalam Karya Lukis Kaligrafi,(Yogyakarta: FPBSIKIP, 1994), 135. 
Second, through freedom of aesthetic expression, art of beautiful writing then with creation form and the arrangement of letters were completed by other elements to be painting work. Third, painting is language of painter. Language is communication media. Painting with its elements is being a symbol used by the painter to reveal the contents of his heart with the messages. Fourth, in the process, the calligraphy painting cannot be separated from the Islamic life. Therefore, calligraphy painting expresses a religious form. Medium of creating work of calligraphy painting is free. As free as medium that used to the general. Classic text is writings have been known and used by the nations who have had culture and the ldest civilization in this world, like Babylonian, Egyptian ancient, Chinese, Phonics, zomans and Arabic.21 Writing is the ancient way that used by people to express the feeling, thinking and hoping in streaks or scratches. Writing is the communication media was known in the culture and civilization of people. ${ }^{31}$ Writing is as symbol of language called script or khat.

The development of khat or calligraphy in Islamic history experienced some obstacles, but it does not make the nations which incidentally rapid development of calligraphy to give up. Like in the Ottoman, in the 14th century system of government is not stable, but they could defeat Mameluk rulers and melt almost of Arabic world. And also in the Islamic art history showed their love of calligraphy, even they created

kind of models pure "indigenous writing". Persian could develop the ta'liq and nasta' liq writing, which is used to create the big masterpiece. Calligraphy of animal nature which came in the 15th century, which used thuluth, naskhi, ta'liq and nasta'liq used to create shapes like animal. The part of top is occupied vertical letters, sometimes composed in the form of a human figure. ${ }^{32}$

Calligraphy style that has served the calligraphers has profound religious values. The beauty of letter strung together with other letters composed in the form of humans, animals and plants with the various meanings. The classical styles as will the author describes a typical style of the Middle East, like Persian and Turkey. Classical style stressed to the meaning of work than just the displaying, whereas the modern style stressed in the displaying. ${ }^{33}$

The following are the expression of classical figurative calligraphy painting: a praying worshiper, a lion figure, an 'Anqa Bird, a Tughra, a Guava Fruit, and a man in Tahiyat.

\footnotetext{
${ }^{31}$ C. Israr, Dari Teks Klasik Sampai ke Kaligrafi Arab, (Jakarta:Yayasan Masagung, 1985), 3.

${ }^{32}$ C. Israr, Dari Teks Klasik Sampai ke Kaligrafi Arab, (Jakarta:Yayasan Masagung, 1985), 6.

${ }^{33}$ M. Abdul Jabbar Beg, Seni di dalam Peradaban islam, (Pustaka, Bandung, 1988), 58
} 


\section{Symbolic Interaction in Figurative Calligraphy Painting}

Arabic calligraphy has been pioneering the way of knowledge, as well as writing in all languages. ${ }^{34}$ Although, calligraphy developed in various forms and cover a wide range of function and areas that are not directly connected to al Qur'an text, there is a relation principally between calligraphy that begin from al Qur'an context only, and spiritual substance Qurean continues to grow in all aspects of Islamic calligraphy. Calligraphy came to occupy a special position in Islam, so it can be referred to as the ancestor visual arts of Islam and has a special position in Islamic civilization. ${ }^{35}$

Calligraphy is the basic of coupling points and lines in various forms and rhythms that never ceases to stimulate memory (tidhkär or dhizkr) through divine pen. Qalam or pen is the active pole of divine creation that allows realizing the divine archetype hidden in magical repertoire in lawh Al-Mahfü along with letters and words that are paradigm all over the form of world. The pen is used to write is a direct symbol of Qalam Allah, and calligraphy is the shadow of God's calligraphy that wrote the realities in the universe. ${ }^{36}$

By submitting oneself to the will of God, the artist made himself as a pen in the Hands of God. Artist such as the pen that with it he wrote down the sheets of life as a masterpiece either in form or content. The works were forms of divine incarnation medium, which enables the formation of norms. The entire of Qur'an is contained in the surah alFätihah, and surah al-Fätịhah is contained in basmalah, and basmalah is contained in ba', and $b a^{\prime}$ is contained in point. Allah is a point. An only person who has relation with source of point that can become a pen in Hand's God and a medium to create Islamic calligraphy, which whole of it comes from the source is Supra-individual.

In the next development, calligraphy is not only evolved limited to beautiful writing and according to the rules, but it also began to be developed in visual art. The presence of calligraphy painting got various response and reactions, even the often harsh reaction and lead to a declaration of war. That's because the artists in painting calligraphy without involving rules pattern khattiyah. The calligrapher assumed that the painters have strayed. This is due to the fact that many of mistakes often found writing letters from lack of caution or lay in their paintings. Either the mistake in putting the point, the less of nibrah, less or more points, therefore feared would create different meaning.

Critics on the calligrapher also required, the painter consider them is poor of shades and does not offer a unique idea, because they just stare at the models that have been pioneered by the classical master in Middle East. Certainly, it is patent that they write on plain white paper with black ink. Even when they have to turn to the media that require

\footnotetext{
${ }^{34}$ Kamil Al-Baba, Dinamika Kaligrafi Islam, translator: Drs. D. Sirojuddin AR., (Jakarta: Darul Ulum Press, 1992), 55.

${ }^{35}$ Seyyed Hosein Nasr, Spiritualitas Dan Seni Islam, translator: Drs. Sutejo, (Bandung: IKAPI, 1993), 29

${ }^{36}$ Seyyed Hosein Nasr, Spiritualitas Dan Seni Islam, translator: Drs. Sutejo, (Bandung: IKAPI, 993), 31
} 
color, purity letters remain dominant and not susceptible to deformation. Therefore, they were dubbed "just finished the letters" by calligraphy painter. According to the painter, it was very saturating. Thus, need for new and unique ideas to express an idea in a work of art. $^{37}$

Through calligraphy strokes, Moslem artists interact to the society by the work of art, it is the figurative calligraphy painting with symbolic interaction. They want to convey the message, the religious message. Posts contain praying illustrated in the form of 'àbid is praying. It contains the meaning that human is weak creature and always does wrong. Therefore, humans need forgiveness from Allah.

Posts of ' $\bar{A} \overline{l i}$ Ibn Abi Tâlib was illustrated in the form of lion. It describes and contains the meaning of braveness and heroism of Ali in defense of Allah religion. The post of "basmalah" in the form of 'anqa' bird has the message about Rahmān and Rahīm of Allah. And the other post of "basmalah" in the form of tughra has the meaning about a wise. Pieces verses of Qurean about Prophet Solomon as., in the form of guava fruit that has the meaning the best gift is following Islamic religion. Shahadat was illustrated in the form of 'äbid in tahiyät. It contains the expression meaning of totally submission to Allah.

From the idea and message aspect, the calligraphy painter wants to do interaction to other people through calligraphy painting. In this case, painting calligraphy is one of communication medium between idea of artist and public art. In order to be fast and deep and memorable the public art has religious consciousness quality. The calligraphy painter makes Allah as the inspiration in create the work. That is, what makes them special than other, the beauty that is displayed is an expression of the majesty of Allah is Jamāl wa Kamāl. In other word, their work is an expression of the form of Allah, Perfect in Beauty and Almighty.

While self-owned by the calligraphy painter used the figurative symbols that are easily understood by the public art. This is one of the advantages of artist to choose the figurative calligraphy painting, which makes the public art easy to interpret the meaning of that painting. Self of artist appears in the form of 'abid is praying as the symbol of disability and resignation to Allah, from of lion is the symbol of braveness and heroism, form of 'anqa bird is symbol of affection of Allah, the form of tughra is the symbol of wisdom, form of guava fruit is the symbol of gift, and form of 'abid is tahiyat as the symbol of tawhid. Simply, through the figurative symbols, although the public art do not know the Arabic writing, they were able to guess the meaning of painting through the figurative symbols. Because, artist used the common figurative symbols which easy to understand.

Furthermore, the work can affect the mind and self of society as the public art. Public art will face to symbolic interaction such as: the expression of 'ābid in praying, lion, 'anqa

\footnotetext{
${ }^{37}$ Kamil al-Baba, op. cit., vii-viii.
} 
bird, tughra, guava fruit, and 'äbid is tahiyat. It is one way the artist invites the public art to interact through figurative calligraphy paintings, in order the mind and self of public art can understand the meaning and message of the painting, especially, the ethics and aesthetics messages in the figurative calligraphy painting.

\section{E. Ethical and Aesthetical Message in Classical Figurative Calligraphy Painting}

According to I Wayan Sadra, the first orientation of artist in the work is value. Value is viewing and believing of something good, beautiful and right. Because value relates to option, thought, and personal acts, so the believing of good, beautiful and right is determined by artist itself. According to him, the good work is the work that was created based on good understanding about the object reality truth for his work. The truth reality is not sense, but essence is spiritual or idea. ${ }^{38}$

As the author has been explained before about the figurative calligraphy painting, so the moral message in the expressions of figurative calligraphy painting could be explained as follow:

First is the expression of figurative calligraphy painting in the form of 'abid in praying. This item described human as a weak creature and always does wrong. Therefore, humans need forgiveness from Allah. It was painted with his feet and lifted his hand up. An expression of relief petition due to inability to pay the punishment for sin and the wrong that was done to Allah. Because it can be, Allah will punish people in the Hereafter for the sins that have been done in the world, although the reasons forgotten and wrong to act that is forbidden. And it can be, Allah will give liability and heavy loads. But, actually the wrong and forgetting are two things that can be expected to receive forgiveness, if the person who made a mistake has struggled mightily and hold firmly to the principles of his religion does not do it anymore. And Allah will not impose a burden on his creatures, but according to their ability. They will receive the reward of good deeds and the sins of the crimes done. ${ }^{39}$

It is undeniable that everything is Allah's willing, factors causing the absence of punishment for forgetting and by mistake was due to receive forgiveness from Allah. And factors causing the absence of heavy loads and difficult is because it gets maghfirah and

\footnotetext{
${ }^{38}$ Bambang Sunarto, 2010, Etika dan Pertimbangan I Wayan Sadra dalam Penciptaan Karya Seni. http://bsunarto.blogspot.com/2010/09/etika-danpertimbangan-i-wayan-sadra.html?m=1., accessed 23 March 2015

39 Al-Faruqi Isma'il Raji, Seni Tauhid Esensi Dan Ekspresi Estetika Islam, penerjemah: Hartono Hadikusumo, (Yogyakarta: Yayasan Benteng Budaya, 1999), 152.
} 
grace of Allah. So, as a human being must be grateful to Allah. Prayer is an expression of a sign of gratitude for favors that have been given by Allah. ${ }^{40}$

Second is the expression of figurative calligraphy painting in the form of lion. Commonly, lion is a symbol of braveness and firmness. It was also the artist depicts the figure of Sayyidinā $\bar{A} \overline{l i}$ bin Abi Tăalib, as a role model who has the braveness in war and the firmness in leadership. Ali was one of the heroes in Islam who dared to defend the Islamic religion. Therefore, do not be surprised if he was dubbed the Lion of Allah.

Third is the expression of figurative calligraphy painting in the form of 'anqa. Anqa is a colossal bird that becomes a symbol of the king of all birds in the universe. The painter gives a great moral message in the painting, which was mention in lafadh Basmalah in the form of 'anqa bird. Basmalah is substance of the Qur'an, secret of the entire Qur'an is composed of 6666 verses, 114 surah, and 30 chapters was summed up in a surah al-Fätihah, and the secret of all surah al-Fätihah was summed up in Basmalah, and the secret of Basmalah was summed up in $b^{\bar{a}}$.' And it was summed up in the point under $b^{-} \bar{a}^{41}$

The relation between 'anqa bird and basmalah is containing the meaning of the origin of all things. In essence, Allah is as the origin of everything that has very broad affection. Everything comes from Allah and will return to Him.

From some of the analysis conducted by the author, in addition to ethical values as has been the author explained earlier, there is also an error in the placement of the sentence. Where, it could reduce the ethical values in the painting. Like sentence of "Allah" written on the back of the painting of the bird. It showed unethical value in the placement of the sentence. The sentence of Allah is the Supreme sentence, should get a great place anyway even if only in a painting.

Fourth is the expression of figurative calligraphy painting in the form of Tughra. Tughra is a symbol for names and nicknames of Sultan that have a wise characteristic. But, in this case, the painter used great lafaz 'basmalah'. Basmalah is the great lafz that was always read by Moslem at every activity. That is expression of inner most self as worship. Wise Moslem is person who does activity as the worship to search of Allah's blessing. ${ }^{42}$

Fifth is the expression of figurative calligraphy painting in the form of guava fruit The painter chose fresh guava fruit that as if freshly picked. The symbol of guava fruit in the painting is the gift. It was as Solomon's story that invites Queen of Balqis to worship of Allah. The gift that contains "Basmalah" means that Allah is the Beneficent and the Merciful is the only God to be worshiped and adored. In other word, the best gift is following the God's religion, it is Islam.

\footnotetext{
${ }^{40}$ Ahmad Musthafa Al-Maraghi, Tafsir Al-Maraghi, penerjemah; Bahrun Abubakar, Lc., K. Anshari Umar Sitanggal, Drs. Hery Nur Ely, (Semarang: PT. Karya Toha Putra Semarang, cet. Ke-2, 1993), 149-153.

${ }^{41}$ C. Israr, Dari Teks Klasik Sampai ke Kaligrafi Arab, (Jakarta:Yayasan Masagung, 1985), 45.

${ }^{42}$ C. Israr, Dari Teks Klasik Sampai ke Kaligrafi Arab, (Jakarta:Yayasan Masagung, 1985), 50
} 
Sixth is the expression of figurative calligraphy painting in the form of ' $\bar{A} b i d$ in Tahiyāt. Lafz Shahadatain was painted in the form of 'äbid in tahiyāt is a consequence of testimony and complete submission, and obedience to Allah with knees to the Him. Allah is the creator of the primary and absolute, and different with His creations, it is because transcendence. None of that is similar to the God, because he ees beyond depiction and none could reach Him.16 It reveals the meaning of monotheism (tawhid). And it considered confessing that Muhammad is the servant of Allah ad His Messenger, who was sent to mankind as a whole, and practices all the consequences. That is obeying his orders, confirmed his words, away from his ban and do not worship of Allah except as prescribed. ${ }^{43}$

Aesthetical matters from those calligraphy paintings could be understood from its essential elements, namely the letters of Arabic alphabet. The whole world recognizes that the Arabic alphabet is the most beautiful letters. In addition, the Arabic alphabet is also very compact compared with other letters. Therefore, the Arabic alphabet is recognized as the center of the basis among the writings in the entire world. ${ }^{44}$ In other word, basically calligraphy has aesthetic value contained in each Arabic letters.

In addition to Arabic letters that make beautiful calligraphy, khat also has an important role in realizing the beauty of calligraphy. Khat is the icon of calligraphy, where

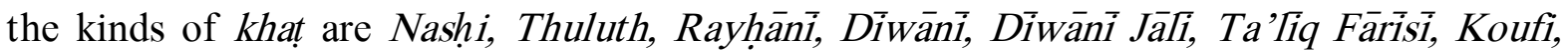
Dan Riq'ah. ${ }^{45}$ Although in calligraphy painting, often ignored the rules of khat, however it did not mean that the artist left khat at all in painting. From some expressions of calligraphy painting in previous chapter can be seen that the artists use good khat. They are able to integrate the khat perfectly. Deviation and mixing between one khat and other is a mistake, because basically it does not fit with the established formula. But in this case, focus of calligraphy painting is not only finished on painted of letters, but also as a whole of painting that makes the letter as the one of its element. Calligraphy painting has freedom in style or the type of writing, so created a unified form of painting that is in accordance with the desire of the artist.

The beautiful value of calligraphy painting was illustrated by the variety of expressions; its letters are lengthened or shortened, widened or narrowed, given additional processed, arch, or signs and additional filler to make it.

The painting has a symbolic of religious, and aesthetic nature is bringing an aesthetic message relate to man and God, man and man, and man and nature. Human as the creature

\footnotetext{
${ }^{43}$ Isma ${ }^{e i}$ il Rajie al-Faruqi, Tawhid; It's Implication for Thought and Life, translator: Rahmani Astuti, (Bandung: Pustaka, 1982), 204.

${ }^{44}$ Kamil al-Baba, op. cit., 6.

${ }^{45}$ D. Sirojuddin AR. Seni Kaligrafi Islam, (Jakarta: Pustaka Panjimas, 1985), 9.
} 
of Allah, whoever he is, if he close and submit to Allah, he will always realize the nature of Allah, perfect in beauty. ${ }^{46}$

In the term of behavior and attitude are not far from the beauty, in creativity is always based on Islamic corridor. In was also done by the artist in expressing his work. Aesthetic message in every the figurative calligraphy painting is a manifestation of the beauty that exists in the universe. That message is one of the manifestations of the One who is Most Beautiful, Allah SWT.; the beauty is realized in the form of latent reality (al-A'yān alThäbitah) and further tangible in the form of "majāzi in the real world. ${ }^{47}$ In other word, that figurative calligraphy painting is manifestation of reflection al-Jalāl wa al-Jamāl Allā (Allah Almighty and The Perfect Beauty).

\section{F. Relation of Ethical and Aesthetical Message in Figurative Calligraphy Painting}

Artists always have inspiration in creating a work; therefore, art spawned a variety of unique and distinctive expressions. This applies also to the calligraphy painters; they made Allah as an inspiration in making the works. The figurative calligraphy painting is described the Majesty, Power, and oneness of Allah SWT., the art was created is the manifestation of tawhid. Therefore, tawhid has the important role in this case; it becomes the important principle in creating the works. ${ }^{48}$

Islamic art is the result of the embodiment of the unity in diversity field. It reflected the containing of divine oneness principle, the dependence of the entire diversity of The Almighty One.21 The form of calligraphy expression is as a constant movement, which is the supreme

God prefix creative attitude, and is one of the main ways to prove the existence of God in this world. Calligraphy is difficult to be understood; therefore it needs effort and preparation, because the pleasure derived is a reflection of a person "es success in a deeper understanding of God. That is moving in His Guidance and shaping conceptions of God. Conception of God is never ending job, it is caused by the emergence of the Arabic language itself, which is connecting the letters with many forms. It led to the emergence of an experience related to the continuity and infinity, which helps to understand God. ${ }^{49}$ Geometries forms described a concept of God with the abstract, because geometries forms signed the infinity of God. Therefore, the relation between ethical and aesthetical message

\footnotetext{
${ }^{46}$ Taufik Djafri, op. cit., 13.

${ }^{47}$ Abdul Muhaya, Spiritualitas Bangunan (Studi Tentang Makna Spiritual Arsitektur Pondok Pesantren Salafiyah Bahru Bihari 'Asali Fadhaailir Rahmah), (Semarang: LP2M IAIN Walisongo Semarang, 2013), 82.

${ }^{48}$ Seyyed Hossein Nasr, op. cit., 18.

${ }^{49}$ Oliver Leaman, Menafsirkan Seni Dan Keindahan; Estetika Islam, translator: Irfan Abubakar, (Bandung: Mizan, 2005), cet. I, 118.
} 
in figurative calligraphy painting can be seen in figurative expression in calligraphy painting, which is incorporated in the dimensions of tawhid.

\section{G. Conclusion}

This article concluded that the ethical moral message of figurative calligraphy could be seen by the way of painter to paint. The artist displayed the works always hold on the Islamic ethic. Their works is good; it means could be accepted by society as the public art. And the important thing is the message of the painting will be received, and it is accordance with the ethics of painting based on the principles of Islamic art and Shari'at of Islam (Al-Qur'ān and Hadith).

The ethical message of figurative calligraphy painting is a post contains praying illustrated in the form of a praying wroshiper. It contains the meaning that human is weak creature and always does wrong. Therefore, humans need forgiveness from Allah. The aesthetical message in every figurative calligraphy painting is a manifestation of the beauty that exists in the universe. That message is one of the manifestations of the One who is the Most Beautiful, reflection al-Jalāl wa al-Jamāl Allāh Allah SWT. Meanwhile the relation between ethical and aesthetical message in figurative calligraphy painting can be seen in figurative expression in calligraphy painting, which is incorporated in the dimensions of tawhid. Figurative calligraphy painting is described the Majesty, Power and Oneness of Allah SWT. Therefore, tawhid has the important role in this case; it becomes the important principle in creating the works. 
The Ethical and Aesthetical Dimension...

\section{Bibliography}

Abineno, J. L. C. H., Sekitar Etika dan Soal-soal Praktis, Jakarta: BPK Gunung Mulia, 1994.

Affandi, M., Ekspresi Simbolik, Religius dan Estetika dalam Karya Lukis Kaligrafi, Yogyakarta: FPBS-IKIP, 1994.

Amin, Ahmad, Etika, Jakarta: Bulan Bintang, 1975.

AR., D. Sirojuddin, Seni Kaligrafi Islam, Jakarta: Pustaka Panjimas, 1985.

Al-Baba, Kamil, Dinamika Kaligrafi Islam, trans., Drs. D. Sirojuddin AR., Jakarta: Darul Ulum Press, 1992.

Beg, M. Abdul Jabbar, Seni di dalam Peradaban Islam, Bandung: Pustaka, 1988.

Bekker, Anton dan Ahmad Kharis Zubair, Metode Penelitian Filsafat, Yogyakarta: Kanisius, 1990.

, Esai Tentang Masalah Aktual Perspektif Etika, Yogjakarta: Kanisius, 2001.

Bertens, K, Etika, Jakarta: Gramedia Pustaka Utama, 1993.

Borchert, Donald M., Philosophy and Ethic, Macmillan Library, 1996.

Bungin, Burhan, Penelitian Kualitatif; Komunikasi, Ekonomi, Kebijakan Publik, dan Ilmu Sosial, Jakarta: Kencana Perdana Media Group, 2010.

Al-Faruqi Isma'il Raji, Tawhid: It's Implication for Thought and Life, trans. Rahmani Astuti, Bandung: Pustaka, 1982.

, Seni Tauhid Esensi Dan Ekspresi Estetika Islam, trans. Hartono Hadikusumo, Yogyakarta: Yayasan Benteng Budaya, , 1999.

, Tauhid; It"s Implication for Thought and Life, trans. Rahmani Astuti, Bandung: Pustaka, 1982.

Gazalba, Sidi, Asas Kebudayaan Islam; Pembahasan Ilmu Dan Filsafat Tentang Ijtihad, Fiqih, Akhlak, Bidang-Bidang Kebudayaan, Masyarakat, Negara, Jakarta: Bulan Bintang, 1978.

Gjafri, Taufik, Menikmati Keindahan Allah Melalui Logika Dan Tanda-tanda, Malang: Bayumedia, 2004.

Israr, C., Dari Teks Klasik Sampai ke Kaligrafi Arab, Jakarta:Yayasan Masagung, 1985

Khan, Maulana Wahiduddin, Islam the Voice of Human Nature, New Delhi: Goodword Books, 2000.

L., W. Does Poprodjo, Filsafat Moral kesusilaan dalam teori dan Praktek, Bandung: Remadja Karya CV, 1986.

Leaman, Oliver, Menafsirkan Seni Dan Keindahan; Estetika Islam, terj, Irfan Abubakar, Bandung: Mizan, 2005.

Makin, Nurul, Kapita Selekta Kaligrafi Islami, Jakarta: Pustaka Panjimas, 1995.

Teosofia: Indonesian Journal of Islamic Mysticism, Volume 5, Number 2, 2016 
Muhaya, Abdul, Spiritualitas Bangunan (Studi Tentang Makna Spiritual Arsitektur Pondok Pesantren Salafiyah Bahru Bihari, Asali Fadhaailir Rahmah), Semarang: LP2M IAIN Walisongo Semarang, 2013.

Nasr, Seyyed Hosein, Spiritualitas Dan Seni Islam, terj, Drs. Sutejo, Bandung: IKAPI, 1993. Nata, Abudin, Akhlaq Tasawuf, Jakarta: Raja Grafindo Persada, 2000.

Pickthall, Muhammad Marmaduke, The Cultural Side of Islam (Islamic Culture), New Dehli: Kitab Bhavan, 1981.

R., Ilham Khoiri, Al-Quran dan Kaligrafi Arab Peran Kitab Suci dalam Transformasi Budaya, Jakarta: LOGOS, 1999.

Salad, Hamdy, Agama Seni Refleksi Teologis dalam Ruang Estetik, Yogyakarta: Yayasan Semesta, 2000.

Scot, John, Teori Sosial Masalah-Masalah Pokok Dalam Sosiologi, terj, Ahmad Lintang Lazuardi, Yogyakarta: Pustaka Pelajar, 2012.

Soedarso, Seni Lukis Kaligrafi Islam, Yogyakarta: ISI , 1992.

Suseno, Franz Magnis, Etika Dasar Masalah-masalah Pokok Filsafat Moral, Yogjakarta: Kanisius, 1997.

Yudoseputro, Wiyoso, Pengantar Seni Rupa Islam di Indonesia, Bandung: Angkasa, t.th.

Yuliman, Sanento, Dua Seni Rupa, Jakarta: Kalam, 2001.

Yustiono, dkk, Islam dan Kebudayaan Indonesia Dulu, Kini dan Esok, Yayasan Jakarta: Festival Istiqlal, 1993.

Bambang Sunarto, 2010, Etika dan Pertimbangan I Wayan Sadra dalam Penciptaan Karya Seni.

http://bsunarto.blogspot.com/2010/09/etika-danpertimbangan-i-wayan-sadra.html?m=1, accessed 23 march 2015 